\title{
Hope Endures: Reading the Boston Marathon Bombing Through the Lens of Christian Hope
}

\author{
Megan Heeder \\ Boston College School of Theology and Ministry (Brighton, MA)
}

\begin{abstract}
Moral tradition teaches that there are particular clarifying events which aid the renewal of moral freedom, the pursuit of the good, and the promotion of justice. The Boston Marathon bombing is one of those events, inviting theologians to consider what a sacramentally-oriented systematic theology offers society via faith and culture's engagement. Viewing the Boston Marathon bombings through Moltmann's lens of Christian hope shows seeds of it in the community's response: it was forward-looking and called people to action; it anticipated a justice connected to the reign of God; and it called people into communities of hope, like those of the disciples. Engaging the community's response and individual stories from the bombing which embody these three aspects of Christian hope offer a sacramental vision of hope with the potential to give life to a largely secularized culture.
\end{abstract}

\section{Text}

The 2013 Boston Marathon looked to be a beautiful day for a 26.2 mile race. Spectators lined the race's every mile. Boylston Street was thick with supporters watching friends and loved ones cross the finish line. But around 2:49 p.m. two pressure-cooker bombs which had been deposited amongst the finish-line crowds in black backpacks, exploded within a minute of one another. ${ }^{1}$ Three people died (a twenty-three-year-old woman, a twenty-nine-year-old woman and an eight-year-old boy) and over 260 others sustained injuries. A total of sixteen people lost legs, the youngest being a girl aged seven. ${ }^{2}$ A Boston Globe journalist described watching spectators who spent their day on the course high-fiving runners as "just the most basic act of love...and

1 “Boston Marathon Bombing," History.com, accessed April 25, 2018, https://www.history.com/topics/boston-marathon-bombings.

2 "Boston Marathon Bombing," History.com. 


\section{HEEDER: HOPE ENDURES}

knowing how important the Boston Marathon is to this community it just felt like an attack on everyone here." ${ }^{3}$ Many runners completed the marathon for charity, raising thousands of dollars in exchange for a spot in the Marathon as a member of that charity's team; their run was an effort of personal and philanthropic sacrifice. Thus, while some see the Boston Marathon bombings as an example of the human potential to inflict pain, the Boston community's response bears seeds of Christian hope. Moral theologian Andrea Vicini writes:

The moral tradition tells us that, within the continuum of moral life, there are events with a specific importance and relevance. They are instances in which we make a synthesis from among multiple dimensions, gain new insight into ourselves and the situation at hand, experience a renewed moral freedom, resolutely pursue the good, and promote justice. These occurrences have been identified with occasions of conversion, because of the transformations that they can bring about in one's life. ${ }^{4}$

The Boston Marathon bombings and the community's response invites theologians to consider the occasions of transformation that a sacramentally-oriented, systematic theology offers society via faith and engagement with culture. In a cultural climate that increasingly rejects faith as tenable or life-giving, events that are sacramental—insofar as they point to a reality beyond the situation itself-are valuable opportunities to engage society. In the case of the Boston Marathon attack, this can be accomplished by looking through the lens of Jürgen Moltmann's conception of hope at a bombing which may seem to hold only darkness. Moltmann's understanding of hope offers three insights into the sacramental nature of Boston's response to the Marathon bombings: it is forward-looking and thus calls us to action, it anticipates the reign of God and God's justice,

${ }^{3}$ David Abel, "I Was There: Boston Marathon Bombings- Juli and David," video interview, I Was There Video Series, A+E Digital Studios, April 25, 2018, audio, 4:10, 6:40, https://www.history.com/topics/bostonmarathon-bombings/videos/i-was-there-boston-marathon-bombings-juli-and-david.

${ }^{4}$ Andrea Vicini, "Hope Springs: Shaping the Moral Life," in Hope: Promise, Possibility, and Fulfillment, ed. Richard Lennan and Nancy Pineda-Madrid (Mahwah, NJ: Paulist Press, 2013), 171-172. 


\section{HEEDER: HOPE ENDURES}

and it calls us into communities of hope so that we and the world can be transformed in hope of what is to come.

The uniquely human ability to perceive things not only as they are, but as they could be is a sign of our ability to look to the future, to hope, and to act in accord with that hope. For Moltmann, hope and action are fundamentally intertwined; hope is neither an ethereal virtue nor something separated from our human realities as embodied beings. Moltmann writes, "We become active insofar as we hope. We hope insofar as we can see into the sphere of future possibilities. We undertake what we think is possible....If we hope for a future alternative, we shall already change things now as far as possible in accord with that."

Thus hope not only activates the human heart and spirit, breathing new life into realities that were once hardened and stale, but it also moves us to action. When we gaze into the future, rife with possibilities, we cannot help but be moved as we begin to imagine and then actualize those possibilities. While despair, the absence of hope, would whisper that these beautiful possibilities can never be won, hope sings, "perhaps they can — and we will never know if we do not try." Because we look forward and imagine something other than the current reality, we are enlivened to hope such that our imagined reality might become real.

A forward-looking and action-based way of living is apparent in the story of bombing survivor Jeff Bauman and Carlos Arredondo. After the amputation of both his legs above the knee, Jeff Bauman's life consisted primarily of painful physical therapy and innumerable doctor's appointments when he was not attending to these new elements of his life, he laid in bed at his apartment. ${ }^{6}$ Jeff was 27, from Chelmsford, Massachusetts, and worked at the Costco deli while

\footnotetext{
5 Jürgen Moltmann, Ethics of Hope, (Minneapolis: Fortress Press, 2012), 3.

${ }^{6}$ Tim Rohan, "Beyond the Finish Line: The Recovery of a Boston Marathon Bombing Victim," New York Times, July 7, 2013, https://www.nytimes.com/2013/07/08/sports/beyond-the-finish-line.html.
} 


\section{HEEDER: HOPE ENDURES}

earning a portion of his college degree. ${ }^{7} \mathrm{He}$ did not know if his girlfriend of about a year, for whom he had been waiting at the finish line when the bombs went off and whom he hoped to marry, would remain in their relationship, and he did not know for months what his mobility or work prognosis would be. ${ }^{8}$ Yet, each day he completed physical therapy and endured invasive procedures. He undertook what he hoped and put his hope into action, without knowing to what end his work would bring him. As he hoped for a future in which he would walk and build a life with his girlfriend, he began to do what he could to make those hopes real. He incarnated his hope in a future he could not see through a sacramental way of living, his physical therapy and doctor's appointments serving as visible signs of an invisible yet hoped-for future. Jeff's recovery reveals hope's forward-looking, sacramental nature and call to action. Hope is alive in how we live and respond to others in light of a reality that is not yet present; how we not only envision, but choose to actualize the future.

Carlos Arredondo's actions saved Jeff's life: he ran toward the explosion site immediately after the bombs detonated, tied a tourniquet around what remained of Jeff's leg, carried him to a wheelchair, and ran him to an ambulance in the hope that his life and what remained of his legs would be saved. ${ }^{9}$ His action sacramentally pointed to God's reign in what Moltmann describes as: "The endtime is simultaneously the new-time. In the perils of time it lives from hope for the coming of God. It mobilizes energies out of surmounted fears...It presupposes a transformative eschatology and, correspondingly, is itself transforming action." 10

Mobilizing energy "out of surmounted fears," Carlos acted despite the chaos and terror around him. His courage in the face of darkness, motivated by concern for the victims who lay on

\footnotetext{
${ }^{7}$ Rohan, "Beyond."

${ }^{8}$ Rohan, "Beyond."

${ }^{9}$ Rohan, "Beyond."

${ }^{10}$ Moltmann, Ethics of Hope, 5.
} 


\section{HEEDER: HOPE ENDURES}

the sidewalks unable to move, embodied the action of a forward-looking hope that made present God's own love and concern for victims. The justice of God's reign was present as Carlos ministered to Jeff and ultimately saved his life. His action points to a reality that, in the moment of the attack, was "other": while everyone ran away from the bombs, not knowing what would come next, Carlos ran toward them knowing people would need help. Carlos' other-oriented action points to God's reign in which caring for the victimized is valued over darkness, terror, the unknown, or self.

This act of love, goodness, and hope in the wake of an evil act helped those who heard Jeff and Carlos' story or viewed their iconic photo ${ }^{11}$ to recall humanity's inherent goodness and ability to embody hope amidst moral evil. Carlos' sacramental action "presuppose[d] a transformative eschatology" in which even acts of terror can be opportunities for actions. These actions cannot only transform the lives of others, but touch the minds and hearts of those who witness them, imbuing them with reminders of hope's possibility. The awakening to the possibility of hope amidst the bombing's darkness, which the story of Carlos and Jeff invites, could be called an "attentiveness to the messianic awakening" which "lies in attentiveness for the signs of the times." 12 Through these sacramental signs, "God's future is heralded, so that Christian action, inspired by hope, becomes the anticipation of the coming kingdom in which righteousness and peace kiss each other." ${ }^{\prime 13}$ Carlos' actions served to herald God's future, anticipating the coming of God's reign in which righteousness and peace unite. Carlos helped a total stranger, placing his life in danger to do what was right - to help a victim who was helpless without him. This radical self-

${ }^{11}$ Charles Krupa, Boston Bombing Heroes, April 2013, photograph, The Associated Press, as seen in Tim Rohan, "In Grisly Image, a Father Sees His Son," New York Times, April 16, 2013, https://www.nytimes.com/2013/04/17/us/in-grisly-image-a-father-sees-his-son.html.

${ }^{12}$ Moltmann, 6.

${ }^{13}$ Moltmann, 6. 


\section{HEEDER: HOPE ENDURES}

sacrifice is the foundation for God's reign, one of love and peace which overcome fear or selfinterest. Jeff's perseverance and sustained effort toward recovery despite not knowing what his prognosis would be also is a sacramental sign anticipating God's reign. Their examples of making God's reign present invited millions to wait "in attentiveness for the signs of the times," serving as rustlings of the messianic awakening.

In the bombing's wake the Boston community came together to support each other in hope, recognizing their need for one another. Colleen Griffiths writes that "one major aspect of the conversion demanded by hope is a fuller realization of our interdependence, or what the theologian Johann Baptist Metz calls our 'poverty of spirit.""14 As Metz explains it, embracing humanity's poverty of spirit "implies facing the human situation squarely as it is, and knowing full well our incompleteness." ${ }^{15}$ It is neither a comfortable nor popular action to recognize (not resist) our "poverty of spirit." Yet, hope requires it: "In the words of the great existentialist philosopher of hope, Gabriel Marcel, 'there can be no hope which does not constitute itself through a we and for a we...all hope is at bottom choral."'16 Indeed, the responses of hope to the Boston Marathon bombings seem to point us toward recognizing our need for one another in our incompletenessinitially found, perhaps, in the fear, chaos, or other effects of the bombings, but not ending there. Instead, hope draws us into a community that can collectively embody hope in the world, work for justice, and sustain us in our efforts to live hope-filled lives.

Hope exists in community and is embodied in action of support. Over 200,000 individuals, businesses, and community groups contributed to the One Boston Fund, which distributed almost

${ }^{14}$ Colleen Griffiths, "Christian Hope: A Grace and A Choice," in Hope: Promise, Possibility, and Fulfillment, ed. Richard Lennan and Nancy Pineda-Madrid (Mahwah, NJ: Paulist Press, 2013), 12.

${ }^{15}$ Griffiths, "Christian Hope," 12.

${ }^{16}$ Griffiths, 11. 


\section{HEEDER: HOPE ENDURES}

$\$ 80$ million to those affected by the bombings. ${ }^{17}$ Many victims used some of the money given to them to found their own organizations. One such foundation aids amputees in purchasing prostheses while others support victims of acts of terror, natural disasters, and car accidents. ${ }^{18}$ The community's generosity and strength was recognized when, on the first anniversary of the bombing, The City of Boston named April $15^{\text {th }}$ One Boston Day. In the spirit of properly remembering the attack, the city asks citizens to reach out to help others as was done on the day of the bombings. ${ }^{19}$ Attentive to humanity's "poverty of spirit" and need for one another, setting aside One Boston Day offered an occasion for the community to gather as one, united as a community in the memory of immense darkness.

The seeds of hope in the stories of the Boston Marathon bombing are sacramental, pointing to a reality which is already, but not yet. Moltmann's hope is forward-looking and calls people to action, anticipates a justice connected to God's reign, and calls people into communities of hope. The three themes continue to call us, our communities, and our world forward in action, acting in God's justice toward the transformation of conversion. Sacramental hope enkindles conversion's candle in the heart, as Moltmann writes, "[s]o that we shall not respond to hate with hate and shall not pay back the evil things the enemy has done." ${ }^{20}$ Bill, father of the eight-year-old bombing victim Martin, embodies the Boston Marathon bombings' insights into hope by declaring: "We choose love, we choose kindness, we choose peace. This is our response to hate. This is what

\footnotetext{
${ }^{17}$ Travis Andersen, “One Fund winds down operation after giving out \$80m," Boston Globe, December 10, 2016, https://www.bostonglobe.com/metro/2014/12/10/one-fund-boston-charity-for-marathon-bombing-victimswinding-down-operations/E18WKwrGnrbmG2dhbQGqJK/story.html.

${ }^{18}$ Jack Lepiarz, "Marathon Bombing Victims Set Up Charities To 'Pay It Forward'," WBUR News, April 13, 2015, http://www.wbur.org/news/2015/04/13/bombing-victims-pay-it-forward.

${ }^{19}$ Alyssa Creamer, "Mayor Walsh Declares Anniversary Of Marathon Bombings As 'One Boston Day',", WBUR News, March 19, 2015, http://www.wbur.org/news/2015/03/19/one-boston-day-marathon.

${ }^{20}$ Moltmann, Ethics of Hope, 202.
} 


\section{HEEDER: HOPE ENDURES}

makes us different than [the bomber]. ${ }^{.21}$ And, we might add, we live in hope of a metanoia of the heart for all, a transformation enabled by hope's sacramental presence in the world today.

${ }^{21}$ Jennifer Levitz, "Boston Marathon Bomber Dzhokhar Tsarnaev Sentenced to Death, Apologizes to Victims," Wall Street Journal (Eastern Edition), June 25, 2015. https://search-proquestcom.proxy.bc.edu/pdnwallstreetjournal/docview/1943241356/F689CE5067884C22PQ/1?accountid=9673. 


\section{HEEDER: HOPE ENDURES}

\section{Bibliography}

Abel, David. "I Was There: Boston Marathon Bombings- Juli and David." Video interview. I Was There Video Series, A+E Digital Studios, April 25, 2018. Audio, 4:10 and 6:40. https://www.history.com/topics/boston-marathon-bombings/videos/i-was-there-bostonmarathon-bombings-juli-and-david.

Andersen, Travis. "One Fund winds down operation after giving out \$80m." Boston Globe, December 10, 2016. https://www.bostonglobe.com/metro/2014/12/10/one-fund-bostoncharity-for-marathon-bombing-victims-winding-downoperations/E18WKwrGnrbmG2dhbQGqJK/story.html.

Creamer, Alyssa. "Mayor Walsh Declares Anniversary Of Marathon Bombings As 'One Boston Day'." WBUR News, March 19, 2015. http://www.wbur.org/news/2015/03/19/oneboston-day-marathon.

Griffiths, Colleen. "Christian Hope: A Grace and A Choice." In Hope: Promise, Possibility, and Fulfillment, edited by Richard Lennan and Nancy Pineda-Madrid, 3-15. Mahwah, NJ: Paulist Press, 2013.

History.com. "Boston Marathon Bombing.” Accessed April 25, 2018. https://www.history.com/topics/boston-marathon-bombings.

Krupa, Charles. Boston Bombing Heroes. April 2013. Photograph. The Associated Press, as seen in Tim Rohan. "In Grisly Image, a Father Sees His Son." New York Times, April 16, 2013. https://www.nytimes.com/2013/04/17/us/in-grisly-image-a-father-sees-hisson.html.

Lepiarz, Jack . "Marathon Bombing Victims Set Up Charities To 'Pay It Forward'." WBUR News, April 13, 2015. http://www.wbur.org/news/2015/04/13/bombing-victims-pay-itforward.

Levitz, Jennifer. "Boston Marathon Bomber Dzhokhar Tsarnaev Sentenced to Death, Apologizes to Victims." Wall Street Journal (Eastern Edition), June 25, 2015. https://searchproquestcom.proxy.bc.edu/pdnwallstreetjournal/docview/1943241356/F689CE5067884C22PQ/1? accountid $=9673$.

Moltmann, Jürgen. Ethics of Hope. Minneapolis: Fortress Press, 2012.

Rohan, Tim. "Beyond the Finish Line: The Recovery of a Boston Marathon Bombing Victim." New York Times, July 7, 2013. https://www.nytimes.com/2013/07/08/sports/beyond-thefinish-line.html. 


\section{HEEDER: HOPE ENDURES}

Vicini, Andrea. "Hope Springs: Shaping the Moral Life." In Hope: Promise, Possibility, and Fulfillment, edited by Richard Lennan and Nancy Pineda-Madrid, 168-181. Mahwah, NJ: Paulist Press, 2013. 